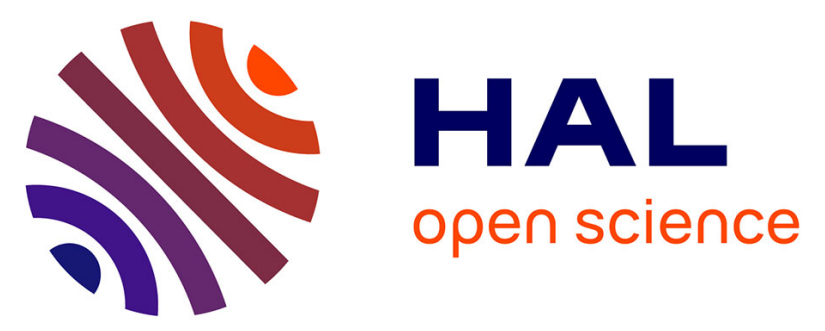

\title{
Late-Holocene climatic variability south of the Alps as recorded by lake-level fluctuations at Lake Ledro, Trentino, Italy
}

Michel Magny, Didier Galop, Paolo Bellintani, Marc Desmet, Julien Didier, Jean Nicolas Haas, Nicoletta Martinelli, Annaluisa Pedrotti, Romana

Scandolari, Agnès Stock, et al.

\section{To cite this version:}

Michel Magny, Didier Galop, Paolo Bellintani, Marc Desmet, Julien Didier, et al.. Late-Holocene climatic variability south of the Alps as recorded by lake-level fluctuations at Lake Ledro, Trentino, Italy. The Holocene, 2009, 19 (4), pp.575-589. 10.1177/0959683609104032 . hal-01187749

\author{
HAL Id: hal-01187749 \\ https://hal.science/hal-01187749
}

Submitted on 27 Aug 2015

HAL is a multi-disciplinary open access archive for the deposit and dissemination of scientific research documents, whether they are published or not. The documents may come from teaching and research institutions in France or abroad, or from public or private research centers.
L'archive ouverte pluridisciplinaire HAL, est destinée au dépôt et à la diffusion de documents scientifiques de niveau recherche, publiés ou non, émanant des établissements d'enseignement et de recherche français ou étrangers, des laboratoires publics ou privés. 


\title{
Late-Holocene climatic variability south of the Alps as recorded by lake-level fluctuations at Lake Ledro, Trentino, Italy
}

\author{
Michel Magny, ${ }^{1, *}$ Didier Galop, ${ }^{2}$ Paolo Bellintani, ${ }^{3}$ Marc Desmet, ${ }^{4}$ \\ Julien Didier, ${ }^{1}$ Jean Nicolas Haas, ${ }^{5}$ Nicoletta Martinelli, ${ }^{6}$ Annaluisa \\ Pedrotti, ${ }^{7}$ Romana Scandolari, ${ }^{8}$ Agnès Stock ${ }^{1}$ and Boris Vannière ${ }^{1}$
}

( CNRS-MSHE Ledoux, USR 3124 (CNRS), and Laboratoire de Chrono-Environnement, UMR 6249, UFR des Sciences et Techniques, 16 route de Gray, 25030 Besançon, France; ${ }^{2}$ GEODE, UMR 5602 (CNRS), Universiy of Toulouse 2, 27 Chemin du Rayat, 31600 Muret, France; ${ }^{3}$ Soprintendenza per $i$ Beni Archeologici, Provincia Autonoma di Trento, via Aosta 1, 38100 Trento, Italy; ${ }^{4}$ ACCES-INRP, 19 Allée de Fontenay, BP 17424, 69347 Lyon Cedex 07, France; ${ }^{5}$ Department of Botany, University of Innsbruck, Sternwartestrasse 15, 6020 Innsbruck, Austria; ${ }^{6}$ Dendrodata s.a.s., via Cesiolo 18, 37126 Verona, Italy; ${ }^{7}$ Dipartimento di Filosofia, Storia e Beni Culturali, Università di Trento, via santa Croce 65, 38100 Trento, Italy; ${ }^{8}$ Museo delle Palafitte del Lago di Ledro, Via Lungolago 1, 38060 Molina di Ledro, Italy)

Received 9 June 2008; revised manuscript accepted 10 January 2009

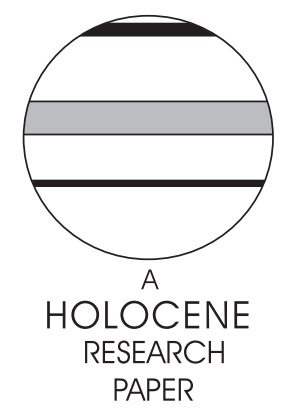

\begin{abstract}
A lake-level record for the late Holocene at Lake Ledro (Trentino, northeastern Italy) is presented. It is based on the sediment and pollen analysis of a $1.75 \mathrm{~m}$ high stratigraphic section observed on the southern shore (site Ledro I) and a $3.2 \mathrm{~m}$ long sediment core taken from a littoral mire on the southeastern shore (site Ledro II). The chronology is derived from 15 radiocarbon dates and pollen stratigraphy. The late-Holocene composite record established from these two sediment sequences gives evidence of centennial-scale fluctuations with highstands at $c .3400,2600,1700,1200$ and $400 \mathrm{cal}$. BP, in agreement with various palaeohydrological records established in central and northern Italy, as well as north of the Alps. In addition, high lake-level conditions at c. $2000 \mathrm{cal}$. BP may be the equivalent of stronger river discharge observed at the same time in Central Italy's rivers. In agreement with the lake-level record of Accesa (Tuscany), the Ledro record also suggests a relatively complex palaeohydrological pattern for the period around $4000 \mathrm{cal}$. BP. On a millennial scale, sediment hiatuses observed in the lower part of the Ledro I sediment sequence indicate that, except for a highstand occurring just after $7500 \mathrm{cal}$. BP, lower lake levels generally prevailed rather before $c .4000 \mathrm{cal}$. BP than afterwards. Finally, the lake-level data obtained at Lake Ledro indicate that the relative continuity of settlements in humid areas of northern Italy during the Bronze Age (in contrast to their general abandonment north of the Alps between c. 3450 and $3150 \mathrm{cal}$. BP), does not reflect different regional patterns of climatic and palaeohydrological conditions. In contrast, the rise in lake level dated to $c .3400 \mathrm{cal}$. BP at Ledro appears to coincide with a worldwide climate reversal, observed in both the hemispheres, while palaeoenvironmental and archaeological data collected at Lake Ledro may suggest, as a working hypothesis, a relative emancipation of protohistoric societies from climatic conditions.
\end{abstract}

Key words: Lake level, late Holocene, northern Italy, sedimentology, Bronze Age lake-dwellings. 


\section{Introduction}

On the basis of $c .150$ tree-ring dates, which establish a robust chronological framework of Neolithic and Bronze Age lakedwellings in west-central Europe, previous studies have shown that the frequency of prehistoric lake-shore villages can be compared with the residual atmospheric ${ }^{14} \mathrm{C}$ record (Magny, 1993). The peaks in frequency correspond to ${ }^{14} \mathrm{C}$ minima (stronger solar activity). In addition to lake-level studies from multiple sediment sequences from lakes north of the Alps, this correlation suggests that higher solar activity induced warmer climate and lake-level lowering, which in turn favoured the expansion of lake-dwellings (Magny, 2004). More particularly, the two tree-ring defined periods 3751-3460 cal. BP (Early Bronze Age and first part of the Middle Bronze Age) and 3070-2764 cal. BP (second part of the Final Bronze Age) corresponded to both a large development of lake-shore villages associated with warmer and drier climate conditions, while after c. 3450 cal. BP, most of the Middle Bronze Age coincided with a general abandonment of lake-dwellings consecutive to a rise in regional lake levels and wetter climate conditions (Magny, 1993, 2004; Zolitschka et al., 2003; Sadori et al., 2004; Magny et al., 2009).

The history of prehistoric settlements in wet areas such as those recognized north of the Alps strongly contrasts with that reconstructed south of the Alpine Mountains. In northern Italy, archaeologists observed not only that a relative continuity of lake-dwellings maintained all through the Bronze Age, but also that the Middle Bronze Age (3600-3300 cal. BP) seems to mark a maximal development of lake-shore and wetland pile-dwelling villages (Perini, 1994; Guidi and Bellintani, 1996; Martinelli, 2005; Magny and Peyron, 2008). The regional peculiarity of northern Italy is still confirmed by the so-called Terramare, ie, fortified villages which developed in humid areas of the Po plain during the Middle and Recent Bronze Age between 3550 and 3100 cal. BP (Cremaschi et al., 2006).

Unfortunately, palaeohydrological records established from high-resolution studies of lacustrine sediment sequences and based on robust chronological data are still rare in northern Italy, to test whether the differences observed between the history of Bronze Age lake-dwellings north and south of the Alps were linked to different regional palaeohydrological patterns or to a different socio-economic organization of societies. As a contribution to such a test, this paper presents a lake-level record established for the last 4500 years at Lake Ledro (Figure 1), which is a site famous for remains of Early and Middle Bronze Age lakedwellings (Battaglia, 1943; Rageth, 1974; Leonardi et al., 1979; Cortesi and Leonardi, 2002). A further and more specific study based on pollen and plant macrofossils will deal with the vegetation dynamics in relation with climate and human impact.

\section{Site and methods}

Lake Ledro $\left(45^{\circ} 87^{\prime} \mathrm{N}, 10^{\circ} 76^{\prime} \mathrm{E}\right.$; Italian: Lago di Ledro) is located at $652 \mathrm{~m}$ a.s.1. on the southern slope of the Alps, at c. $6 \mathrm{~km}$ in the north of Lake Garda (Figure 1). It is a relatively small lake $(2.8 \mathrm{~km}$ long, $0.8 \mathrm{~km}$ wide), its present water depth reaching $38 \mathrm{~m}$. The surrounding mountains culminate at c. 1500-2200 m a.s.1. The lake surface is $c .2 .17 \mathrm{~km}^{2}$ and the catchment area covers $c .131$ $\mathrm{km}^{2}$ and is characterized by relatively steep slopes. The substratum is mainly composed of Triassic (dolomite), Jurassic and Cretaceous limestone. The outlet of Lake Ledro is the Ponale River, which is responsible for downcutting in a morainic dam (Beug, 1964). Since 1929, the water-table has been artificially regulated for hydroelectricity.

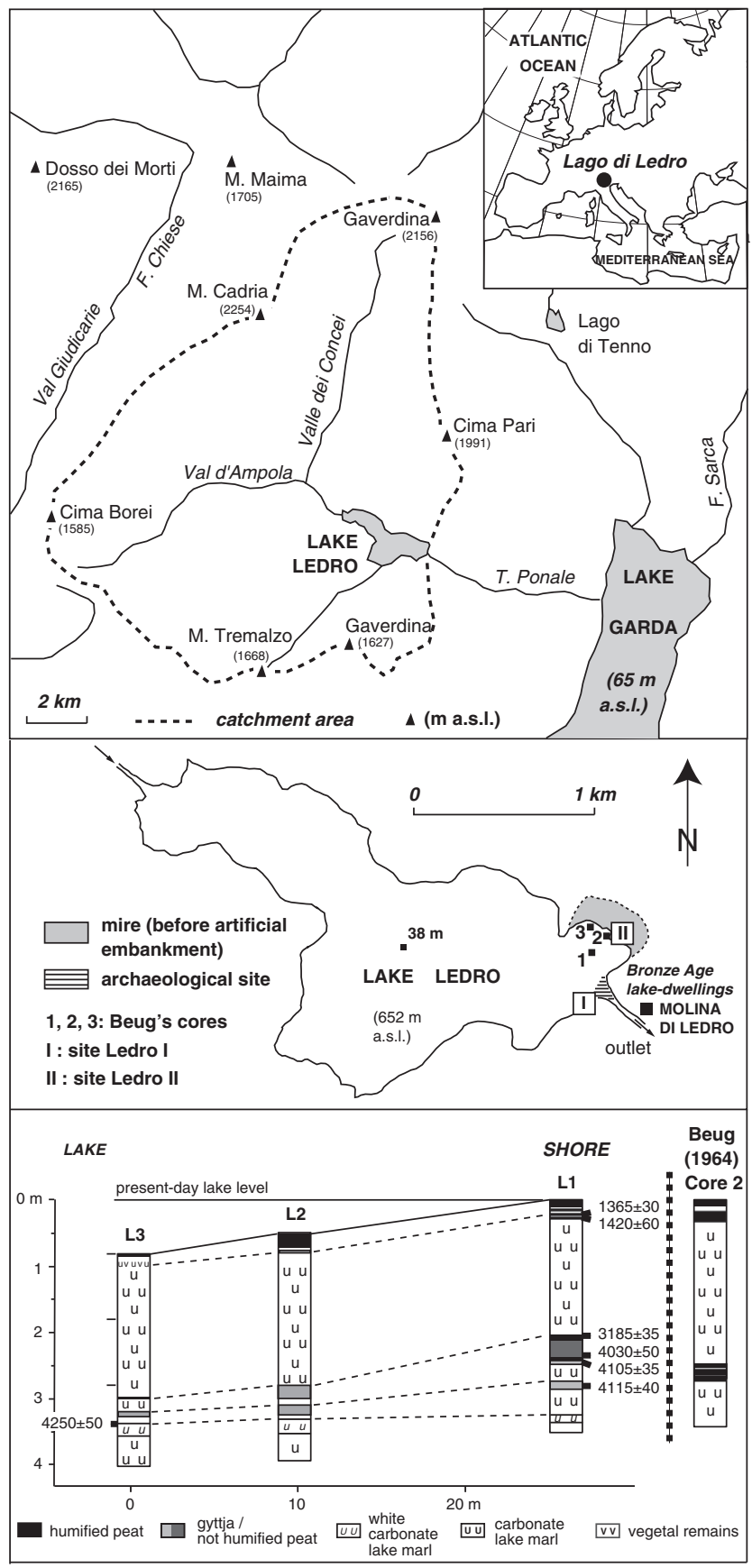

Figure 1 Upper panel: location and catchment area of Lake Ledro in northern Italy. Middle panel: location of sites Ledro I and II (present study), and of coring sites of Beug (1964). Lower panel: core transect established on the site of Ledro II. On the right the lithostratigraphic profile of core 2 pollen analysed by Beug (1964) is shown

Owing to the influence of a large body of water, the region of Lake Garda (65 $\mathrm{m}$ a.s.1.) is famous for particularly mild climatic conditions, which allow the presence of Mediterranean species. Around Lake Garda, olive groves reach $300 \mathrm{~m}$ a.s.l. and isolated olive trees even $600 \mathrm{~m}$ a.s.l. The shores of Lake Garda were also well-known for plantations of lemon trees protected against possible winter frost. Quercus ilex is present in the Sarca valley as well as Erica arborea in the Chiese valley (Figure 1; Beug, 1964). However, because of higher altitude, the vegetation in the Ledro valley is dominated by Fagus mixed with Abies, then Picea in the higher part of the montane belt (650-1600 m), and by Pinus mugo, Alnus viridis, Larix and Picea in the subalpine belt (1600-2000 m). Above $2000 \mathrm{~m}$ a.s.l. grasslands dominate (Beug, 1964). Generally 
Table 1 AMS radiocarbon dates obtained on terrestrial plant macroremains and from littoral peat at sites Ledro I and II

\begin{tabular}{|c|c|c|c|c|c|c|}
\hline Core & Depth $(\mathrm{cm})$ & Radiocarbon date & Calibrated age ( 1 sigma) & Calibrated age (2 sigmas) & Laboratory reference & Material \\
\hline \multirow[t]{8}{*}{ Ledro I } & $47-48$ & $1490 \pm 35$ & 1405-1342 cal. BP & 1509-1304 cal. BP & Poz-11068 & charcoal + bark \\
\hline & $77-88$ & $1870 \pm 30$ & $1868-1740$ cal. BP & 1877-1724 cal. BP & Poz-11069 & wood fragments \\
\hline & $97-98$ & $2195 \pm 30$ & 2306-2151 cal. BP & $2317-2131 \mathrm{cal} . \mathrm{BP}$ & Poz-11070 & wood fragments \\
\hline & $119-120$ & $2250 \pm 140$ & 2451-2009 cal. BP & 2707-1934 cal. BP & Poz-13143 & charcoal \\
\hline & $125-126$ & $3245 \pm 35$ & 3553-3404 cal. BP & 3559-3392 cal. BP & Poz-11893 & charcoal + bark \\
\hline & $140-142$ & $3280 \pm 35$ & $3558-3467$ cal. BP & 3610-3406 cal. BP & Poz-11894 & charcoal \\
\hline & $152-153$ & $3695 \pm 35$ & 4085-3985 cal. BP & 4149-3927 cal. BP & Poz-11072 & charcoal \\
\hline & $172-173$ & $6900 \pm 130$ & 7914-7619 cal. BP & $7972-7514$ cal. BP & Poz-13144 & charcoal \\
\hline \multicolumn{7}{|l|}{ Ledro II } \\
\hline \multirow[t]{6}{*}{ L1 } & $21-22$ & $1365 \pm 35 \mathrm{BP}$ & 1309-1279 cal. BP & 1339-1189 cal. BP & Poz-17035 & peat \\
\hline & $23-24$ & $1420 \pm 60 \mathrm{BP}$ & $1369-1290$ cal. BP & 1507-1184 cal. BP & Poz-18588 & peat \\
\hline & $204-205$ & $3185 \pm 35$ & 3444-3381 cal. BP & $3470-3356 \mathrm{cal} . \mathrm{BP}$ & Poz-17036 & twigs \\
\hline & $236-237$ & $4030 \pm 50$ & $4569-4425$ cal. BP & $4805-4413$ cal. BP & Poz-18596 & peat \\
\hline & $244-245$ & $4105 \pm 35$ & $4799-4530 \mathrm{cal} . \mathrm{BP}$ & $4816-4453 \mathrm{cal} . \mathrm{BP}$ & Poz-17038 & peat \\
\hline & $280-281$ & $4115 \pm 40$ & $4807-4535$ cal. BP & $4822-4524$ cal. BP & Poz-17039 & twigs \\
\hline L3 & $70-71$ & $4250 \pm 50$ & 4865-4662 cal. BP & $4960-4590$ cal. BP & Poz-21190 & wood fragments \\
\hline
\end{tabular}

speaking, in the Ledro valley, mixed oak forest does not develop; lime trees are rare, while elm and maple trees may be present in Fagus forests. At Molina di Ledro, the mean temperature is $c .0^{\circ} \mathrm{C}$ in the coldest month (January) and c. $20^{\circ} \mathrm{C}$ in the warmest month (July). The annual precipitation ranges from $c .750$ to $c .1000 \mathrm{~mm}$, with seasonal maxima in spring and autumn.

Two sites, ie, Ledro I and Ledro II, have been chosen for lakelevel studies (Figure 1). Ledro I is located on the southeastern shore, just west of a place occupied by Middle Bronze Age lake-dwellings in the outlet area. Littoral erosion due to natural factors in combination with large annual fluctuations of water level for hydroelectricity offered the opportunity in April 2005 to observe and sample a $1.75 \mathrm{~m}$ high stratigraphic section above the lowered water level. Overlying morainic deposits and a pebble beach formation, the sediment sequence observed along a $c .100 \mathrm{~m}$ section highlights an alternation of different layers composed of carbonate lake marl, oncolites and peaty sediments. In addition, the geometry of the sediment layers gives evidence of erosion surfaces (see below). Site Ledro II is located on the northeastern shore, in a small littoral mire which is the residual part of a large peat area artificially embanked for the installation of a camping site. There, by means of a Russian peat corer, a $30 \mathrm{~m}$ long core transect perpendicular to the shore, has been carried out to recognize the sediment stratigraphy. Figure 1 (lower panel) shows the upper part of the sequence which is of interest for this study. Considered as a whole, under the superficial peat layer, the sediment sequence shows an accumulation of carbonate lake-marl interrupted by deposition of organic layers (peat, gyttja) which are better developed towards the lake shore. Core L1 was chosen for sediment analysis because it offered the most complete contrasting lithostratigraphical profile with the best development of organic layers. Ledro II is close to coring sites pollen-analysed by Beug (1964) for the Lateglacial and Holocene vegetation history (Figure 1).

Pollen preparation followed standard methods using treatment with $\mathrm{HCL}, 10 \% \mathrm{KOH}, \mathrm{HF}$, acetolysis and final mounting in glycerine. More than 450 terrestrial pollen grains were counted for each sample. Cyperaceae, palustrine taxa, aquatics and spores are systematically excluded from the pollen sum. All pollen types are defined according to Faegri and Iversen (1989), although some identifications require the use of a pollen atlas (Reille, 1992-1998). At Ledro I, the pollen grains were not preserved in the lower part of the sediment sequence below $97 \mathrm{~cm}$ (except for one sample at $120 \mathrm{~cm}$ ), while at Ledro II the pollen preservation, although not always excellent, was good enough to establish a complete pollen diagram. Beyond causes linked to lake-level fluctuations (see below), the differences in pollen preservation between Ledro I and II probably originate from different geomorphologic conditions: site Ledro II is located on the fringe of a large littoral mire favourable to retaining underground water, while site Ledro I is characterized by a narrow littoral zone close to relatively steep slopes of the catchment area.

The lake-level fluctuations were reconstructed using a sedimentological method (Magny, 1998, 2006), based on multiple lines of evidence, including changes in lithology and relative frequency of various carbonate concretion morphotypes of biochemical origin. Modern analogue studies demonstrated that each morphotype shows a specific spatial distribution from the shore to the extremity of the littoral platform, with the successive domination of oncolites (nearshore areas with shallow water and high energy environment), cauliflower-like forms (littoral platform), plate-like concretions (encrustations of leaves from the Potamogetonion and Nymphaeion belts) and finally tube-like concretions (stem encrustations from the Characeae belt on the platform slope). In addition to variations in the assemblages of carbonate concretions, the relative frequency of plant macroremains and mollusc shells provide further information about the deposition environment. The abundance of mollusc shells increases towards the shore (Mouthon, 1984) as do vegetal remains partly inherited from littoral vegetation (particularly lignosous vegetal remains). Moreover, erosion surfaces (sediment hiatuses) evidenced by uncoformities between sediment layers (Mitchum et al., 1977; Digerfeldt, 1988) point to a lowering of the sediment limit associated with a lowering of the lake level.

The chronology is based on 15 AMS radiocarbon dates (Table 1) from terrestrial plant macroremains or from littoral peat deposits. The ages have been calculated using IntCalib 5 (Stuiver et al., 1998). Additional chronological indications are provided by the regional pollen stratigraphy (Figures 2 and 3).

\section{Results}

\section{Vegetation and human-impact history}

The results of pollen analysis are presented in Figure 2. The present study focuses on the general pollen stratigraphy established on the basis of the Ledro II record which provided a complete pollen diagram. One may observe that the main features of the vegetation history reconstructed at Ledro for the late Holocene appear to be 


\section{Site LEDRO I}
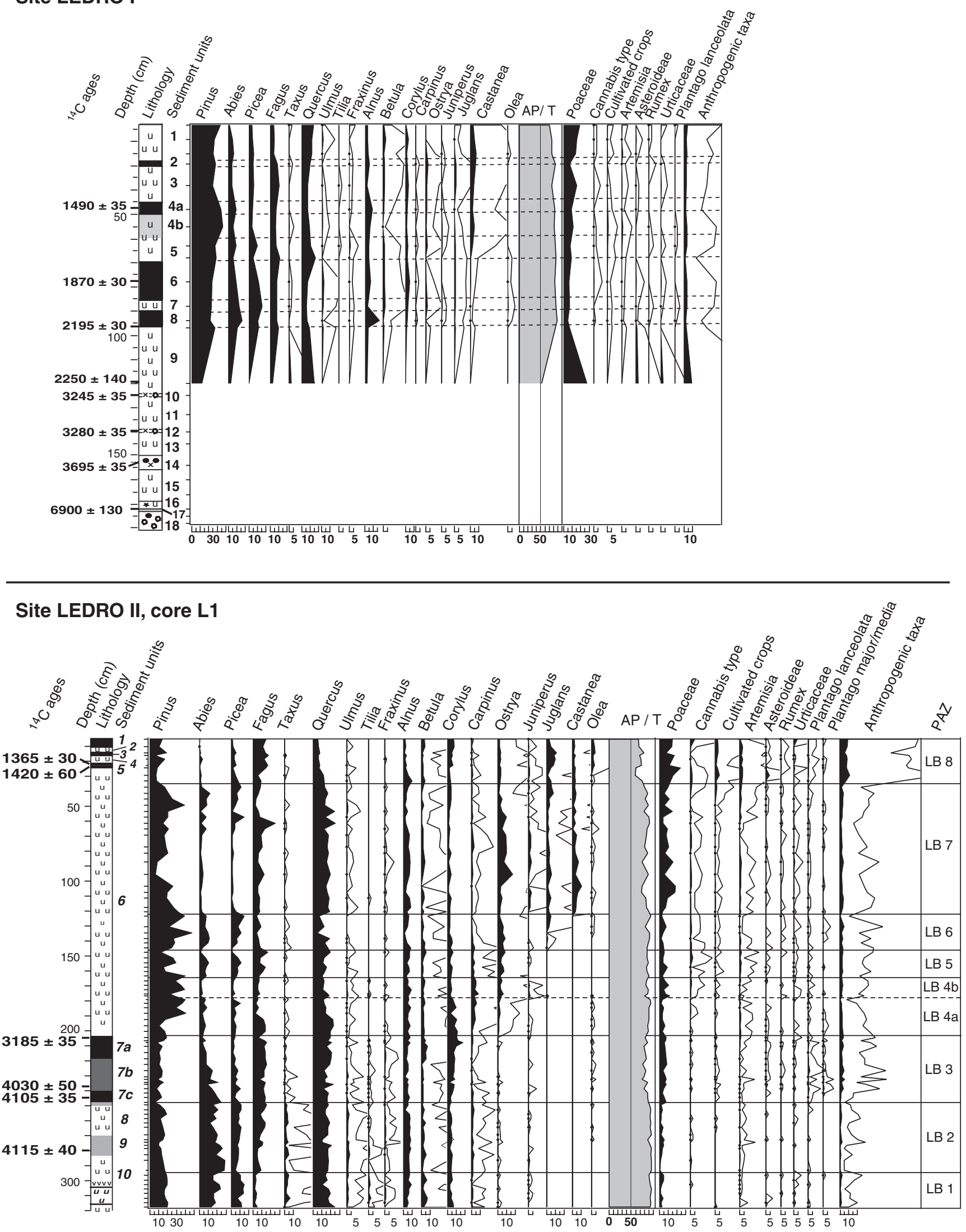

Figure 2 Simplified pollen diagrams of sites Ledro I (upper panel) and II (lower panel). Cultivated crops: Cerealia-type, Triticum-type, Secale; anthropogenic taxa: Plantago major/media-type, Plantago lanceolata, Plantago sp., Artemisia, Urtica, Echium-type, Rumex sp., Rumex acetosa/ acetosela-type, Brassicaceae, Rubiaceae, Chenopodiaceae, Asteroideae, Cichoriodeae, Centaurea cyanus, Papaveraceae. Exaggerated curves are $\times 10$. In the Ledro I sequence, pollen grains were not preserved below level $120 \mathrm{~cm}$. PAZ, pollen assemblage zones 

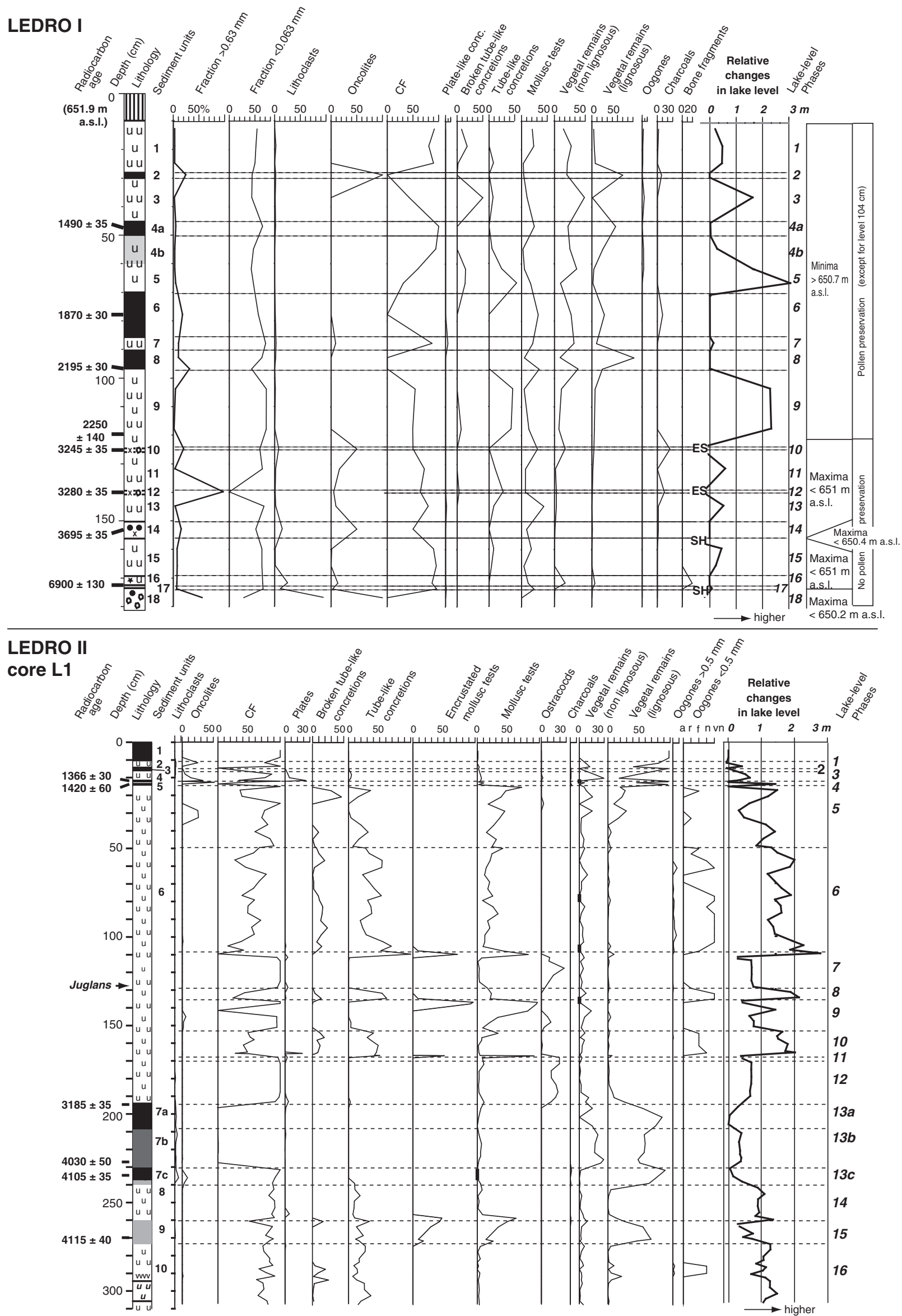

Figure 3 Upper panel: sedimentological diagram and lake-level fluctuations established from site Ledro I. Lower panel: sedimentological diagram and lake-level fluctuations established from site Ledro II. The arrow indicates the development of Juglans as observed by pollen stratigraphy (see Figure 2). ES, erosion surface; SH, sediment hiatus; CF, cauliflower-like concretions. Oogones (fraction < $0.063 \mathrm{~mm}$ ): a, absent; r, rare; f, frequent; n, numerous; vn, very numerous (ie, more than $40 / \mathrm{cm}^{3}$ ) 
consistent with the pollen stratigraphy previously recognized by Beug (1964). The lower part of the sequence (LB1 and LB2 pollen assemblage zones) is characterized by a stronger development of a coniferous forest dominated by Pinus (P. sylvestris type), Abies and to a lesser extent Picea, while Taxus shows a nearly continuous representation with percentages of $c .5 \%$ (less than in Beug's diagrams). A mixed oak forest with Ulmus, Tilia and Fraxinus is also well represented. During pollen assemblage zone LB2 the values of Fagus increase to reach c. 15\%, and Abies surpasses Pinus. From pollen zone LB3, the history of the forest appears to have been characterized by (1) a decrease of the fir-spruce forest punctuated by short intermediate phases of increase (zones LB5, LB6, and upper part of LB7), (2) the quasi-disappearance of Taxus, Tilia and Fraxinus as well as the strong retreat of Ulmus which is only represented by irregular and low values, (3) the expansion of Pinus during pollen zones LB4a and LB4b, with values reaching $30 \%$, (4) the development and the continuous curve of Ostrya from zone LB4a, and finally (5) the successive development of Juglans (zone LB6) and Castanea (zone LB7), while Olea shows an increase during zone LB8. A pollen record recently established at Lago Lavarone in Trentino (Filippi et al., 2007a) gives evidence of similar features, with successive appearances of Juglans and Castanea, respectively dated to $2110 \pm 80 \mathrm{BP}$ (ie, 2310-1920 cal. BP) and c. 1800 BP, ie, 1820-1690 cal. BP (extrapolated age). When taking into account uncertainties inherent in radiocarbon ages, this is consistent with the pollen data obtained from Ledro I sequence where levels 97 and $68 \mathrm{~cm}$ are characterized by the successive developments of Juglans and Castanea and have been dated to 2317-2131 cal. BP (2195 \pm 30 BP) and after $1877-1724$ cal. BP $(1870 \pm 30 \mathrm{BP})$, respectively.

Regarding human-impact history, scarce occurrences of cereal and anthropogenic indicators may show, during pollen zones LB1 and LB2, a low or moderate human pressure near the shores of Lake Ledro. Zone LB3 reflects a strong increase in human activity during the Bronze Age. This is characterized by high values of anthropogenic indicators (cultivated crops and anthropogenic taxa) and by important clearance of forest as shown by a synchronic reduction of forest taxa such as Abies, Picea, Taxus and Ulmus. In zone LB4a, the quasi-disappearance of the cereal pollen-type, and the decrease in anthropogenic taxa (Urtica, Plantago lanceolata, Rumex) may reflect a short period of reduction in agro-pastoral activities, immediately followed by a new increase of human pressure in zone LB4b. As indicated by pollen data, human activities such as cultivation (probably including Cannabis cultivation; Mercuri et al., 2002) and grazing remain stable and regular until the top of the record. The increase in Poaceae and the strong reduction of the fir-spruce forest recorded during zone LB7 reflect the development of open areas during the Roman period, probably linked to an intensification of forest clearances. However, the Medieval period seems to be most important for human activities in the Ledro region. All anthropogenic indicators show a strong increase correlated to a reduction of forest cover.

\section{Lake-level fluctuations}

Figure 3 shows sediment diagrams established from Ledro I and II sediment sequences. On the right, curves of relative changes in lake level indicate the ratio between the total scores of markers of low lake-level conditions (ie, oncolites and cauliflower-type concretions, encrusted mollusc tests, lignosous vegetal remains), and those of high lake-level conditions (ie, plate and tube concretions, oogones of Characeae; Magny, 1998, 2006).

The Ledro I sediment sequence appears to have been affected by several hiatuses and erosion surfaces because of (1) relatively high elevation a.s.1., and (2) the general Holocene history of the lake level. The curve of relative changes in lake level shows 18 distinct successive phases of high and low water-table as follows (Figure 3).

On top of the basal morainic deposits a pebble beach layer is observed characteristic for lake-shore sedimentation. This phase (18) developed before $6900 \pm 130$ BP (ie, 7972-7514 cal. BP). A slight rise in lake level (phase 17) provoked the sedimentation of a first thin carbonate lake-marl layer, which overlies the morainic deposits. Afterwards, the Ledro I sediment sequence gives evidence of eight successive phases of low lake level marked by peaks of oncolites, lithoclasts (terrestrial input) and coarser texture (phases 16, 14, 12 and 10), or by the formation of peat layers (phases 8, 6, 4 and 2). Unconformities between sediment layers highlight the development of erosion surfaces during phases 12 and 10, while radiocarbon ages point to sediment hiatuses before $3695 \pm 35$ (ie, 4149-3927 cal. BP) and $2250 \pm 140 \mathrm{BP}$ (ie, 2707-1934 cal. BP). Unfortunately, sediment unit 2 (peat) provided an inconsistent radiocarbon age probably because of reworked material. An extrapolated age of $c$. $750 \mathrm{cal}$. BP can be assumed for sediment unit 2 . Intermediate phases $17,15,13$, $11,9,7,5,3$ and 1 correspond to higher lake-level conditions marked by accumulation of carbonate lake-marl with a finer texture, the development of plate and tube concretions and a decline of oncolites. Phases 9 and 5 point to major rises in the water-table as indicated by peaks of tube concretions (Figure 3).

Regarding the chronology of the sediment diagram established from the sediment sequence Ledro II, no sufficient and appropriate organic material has been found to obtain radiocarbon dates from sediment unit 6 . On the other hand, it seems difficult to extrapolate ages assuming a regular sedimentation rate because several abrupt jumps in the representation of encrusted mollusc tests (characteristic for lake-shore sedimentation) and tube concretions (indicators of maximums in lake level) point to possible short sedimentation hiatuses at levels 178, 146 and $118 \mathrm{~cm}$. Such a jump also appears at level $270 \mathrm{~cm}$. However, the pollen stratigraphy, with the successive development of Juglans and Castanea at levels 138 and $120 \mathrm{~cm}$, respectively, provides additional chronological references (see above).

The curve of relative changes in lake level shows 16 distinct successive phases as follows (Figure 3). During phase 16 which occurred before $4115 \pm 40 \mathrm{BP}$ (ie, 4822-4524 cal. BP), generally high lake-level conditions prevailed (development of tube concretions). Stratigraphic correlation between cores L1, L2 and L3 (Figure 1) allows dating of phase 16 to $c .4250 \pm 50 \mathrm{BP}$ (ie, 4960-4590 cal. BP). Phase 15 coincides with a lowering marked by the deposition of gyttja (sediment unit 9) and a peak in encrusted mollusc tests. Between $4115 \pm 40$ and $4105 \pm 35$ BP (ie, between $4822-4524$ and $4816-4453 \mathrm{cal}$. BP), phase 14 corresponds to higher lake-level conditions provoking the cessation of gyttja deposition and the disappearance of encrusted mollusc tests. From c. $4105 \pm 35$ BP to $3185 \pm 35$ BP (ie, from 4816-4453 to $3470-3356$ cal. BP), phase 13 is characterized by prevailing low lake-level conditions, which favoured the deposition of organic layers. However, in sediment unit 7, the interbedding of a layer composed of not humified brown peat between two humified black peat layers suggests that phase 13 was interrupted by a slight rise event. As illustrated by Figure 1, the profile of core 2 studied by Beug (1964) shows a more complex picture for sediment unit 7 with two gyttja layers interbedded between three peat layers.

After $3185 \pm 35$ BP (ie, 3470-3356 cal. BP), the return to carbonate lake-marl sedimentation points to a new rise in lake level (phase 12) which later reached successive maxima (phases 10, 8 and 6) well marked by peaks in tube concretions and oogones of Characeae. Peaks of encrusted mollusc tests give evidence of pronounced intermediate lowering episodes (phases 11, 9 and 7). Two successive peaks in oogones of Characeae suggest that phase 6 is composed of two distinct events. Generally speaking, phase 5 marks a trend towards lower lake-level conditions (development 
of mollusc tests, oncolites, cauliflower concretions, strong decline in oogones). In the upper part of the sediment sequence, the alternation of carbonate and peat layers reflects the succession of highstands (phases 3 and 1) and lowstands, ie, phase 4 composed of two successive events dated to $1420 \pm 60$ (ie, 1507-1184 cal. BP) and $1365 \pm 30$ BP (ie, 1339-1189 cal. BP) and phase 2. Recent archaeological excavations allow more precise dating of phase 4 to $c .1380-1330 \mathrm{cal}$. BP on the basis of archaeological artefacts found in sediment unit 5 (Dal Ri and Piva, 1987). Hence, an extrapolated age of $c .1000 \mathrm{cal}$. BP can be assumed for phase 2 .

Taking into account radiocarbon dates in addition to the pollen stratigraphy and the palaeohydrological signal (highstands versus lowstands), the comparison of the two lake-level records Ledro I and Ledro II make it possible to establish (1) correlations between centennial-scale events recognized from both sites, and (2) a synthetic lake-level record for Lake Ledro as illustrated by Figure 4. The main difficulties for these correlations arise from sediment unit 6 of sequence Ledro II which did not provide any radiocarbon dates. However, the pollen stratigraphy suggests that phase 7 of Ledro II (characterized by the beginning of the development of Juglans at level $138 \mathrm{~cm}$, and absence of Castanea until level 120 $\mathrm{cm}$ ) may be an equivalent to phases 6,7 and 8 of Ledro I (marked by the development of Juglans while Castanea is still poorly represented). Hence, phase 6 of Ledro II appears to be an equivalent to phase 5 of Ledro I, characterized by a more pronounced development of Castanea just after $1870 \pm 30$ BP, ie, 1877-1724 cal. BP (Figure 2). Subsequently, phase 8 of Ledro II may be an equivalent to phase 9 of Ledro I. Owing to the lack of radiocarbon dates in sediment unit 6 of Ledro II, in addition to the absence of preservation of pollen grains below level $120 \mathrm{~cm}$ and the sediment hiatus between sediment units 10 and 9 at Ledro I, it remains impossible to firmly indicate any equivalent to phases 10 and 11 of Ledro II in the sequence Ledro I. However, the chronological proximity of phases 12 and 10 of Ledro I suggests that the period of higher lake-level conditions following phase 13a at Ledro II composed of distinct successive highstand phases. Hence, phase 10 of Ledro I may be correlated with phase 11 of Ledro II.

In addition to a series of centennial-scale palaeohydrological events illustrated by Figure 4, the sediment sequence Ledro I suggests millennial-scale variations over the late Holocene (Figure 3, upper panel). First of all, it is remarkable that no sediment deposition occurred on the site of Ledro I during the first part of the Holocene. The first significant accumulation of lacustrine sediment, ie, the $15 \mathrm{~cm}$ thick sediment unit 15 , developed just after $6900 \pm 130$ BP (ie, after c. $7500 \mathrm{cal}$. BP), as suggested by the preservation of the thin sediment units 17 and 16. But, the composition of sediment unit 15 indicates that lake-level maxima did not go beyond $651 \mathrm{~m}$ a.s.l. Afterwards, the sediment hiatus observed between sediment units 15 and 14 reflects a period of low lake-level conditions (before $4000 \mathrm{cal}$. BP) with maxima of the water-table less than $650.4 \mathrm{~m}$ a.s.l. (no sediment deposition). Thereafter, the sediment sequence of Ledro I shows two successive periods. The first, corresponding to the deposition of sediment units 14 to 10 , is characterized by erosion surfaces and/or sediment hiatuses as well as by no preservation of pollen grains. In contrast, the second period from sediment units 9 to 1 shows a better preservation of pollen grains (sufficient to establish a diagram, except for level $104 \mathrm{~cm}$ ), and gives evidence of a relatively continuous sedimentation. Alltogether, these observations suggest three distinct successive periods as follows (Figure 3).

- Before $6900 \pm 130$ BP (ie, 7972-7514 cal. BP), the water level is lower than the top of the basal moraine (unit 18), ie, below $650.2 \mathrm{~m}$ a.s. 1 .

- In the second period, a rise in lake level led to the deposition of sediment above $650.15 \mathrm{~m}$ a.s.l. during pronounced highstands, while lowstands provoked the cessation of deposition and the formation of sediment hiatuses and erosion surfaces (sediment units 14,12 and 10). It is noteworthy that between $c$. 7000 and $4000 \mathrm{cal}$. BP even maximal lake levels remained below $650.4 \mathrm{~m}$ a.s.1. (no sediment deposition).

- Finally, during the recent third period, since $c .2250 \pm 140 \mathrm{BP}$ (ie, 2707-1934 cal. BP), the lake level reached a higher point and sedimentation became relatively continuous above 650.7 $\mathrm{m}$ a.s.l., even during the lowstands which coincided with peat accumulation (sediments units 8, 6, 4 and 2).

\section{Discussion and conclusions}

Keeping in mind the radiocarbon-age uncertainties, Figure 5 presents a comparison between the centennial-scale fluctuations of lake level reconstructed at Ledro for the last 4500 years and (1) the regional pattern of lake-level changes established for west-central Europe north of the Alps (Magny, 2004, 2006), as well as (2) various palaeohydrological records from central Italy, ie, Lake Fucino (Abruzzo; Giraudi, 1998), Lake Mezzano (Lazio; Giraudi, 2004; Sadori et al., 2004), Lake Accesa (Tuscany; Magny et al., 2007a) and the Ombrone River delta (southern Tuscany; Bellotti et al., 2004), and Calderone glacier in the Gran Sasso Massif (central Apennines; Giraudi, 2005a, b). Taking into account the difficulties linked to the fact that records have been established from different methods and differ in the precision of their temporal resolution and chronology, Figure 5 shows that, within the age uncertainties inherent in radiocarbon dating, lakelevel records from Ledro, Fucino, Mezzano and Accesa give evidence of similarities with highstands at c. 3400, 2700, 1200 and 400 cal. BP. Lake Ledro also displays a well-marked highstand episode which developed after $2195 \pm 30$ BP (ie, 2317-2131 cal. $\mathrm{BP}$ ) and before $1870 \pm 30 \mathrm{BP}$ (ie, 1877-1724 cal. BP), and may be synchronous with the one observed at Lake Fucino (Giraudi, 1998) at c. 2000 cal. BP as well as with marked floods at the same time in valleys of the rivers Tiber in Roma (Camuflo and Enzi, 1994; Giraudi, 2005b) and Arno in Pisa (Benvenuti et al., 2006) in Italy, and in the Rhone delta in France (Arnaud-Fassetta, 2002).

Regarding the period around $4000 \mathrm{cal}$. BP, the sequences Ledro I and II provide contrasting data. While a lake-level lowering dated to $3695 \pm 35 \mathrm{BP}$ (ie, 4150-3930 cal. BP) is observed at Ledro I, the sequence of Ledro II shows a slight rise in lake level which occurred between $4030 \pm 50$ BP (ie, 4805-4413 cal. BP) and $3185 \pm 35$ BP (ie, 3470-3356 cal. BP). Moreover, the profile of Beug's core 2 highlights a more complex lithostratigraphy for sediment unit 7, with two gyttja layers interbedded between three peat layers (Figure 1, lower panel) and suggest two successive slight rises in lake level. These contrasting data may reflect differences of elevation between the two sites, but they may also point to a more complex picture of the $c$. $4000 \mathrm{cal}$. BP cooling event (Marchant and Hooghiemstra, 2004) in the northern Mediterranean area than was previously thought. A multiproxy record from Buca della Renella, a cave in the Alpi Apuane (central-western Italy), has shown a severe drought dated to $c .4100$ cal. BP synchronous with an IRD event in the North Atlantic Ocean (Bond et al., 2001; Drysdale et al., 2006). However, Piva et al. (2008) found evidence of a wetter and cooler event at $c$. 4000-3800 cal. BP from marine cores in the Adriatic Sea. In addition, as illustrated by Figure 5, the Accesa lake-level record in central Italy shows two marked low lake-level episodes at $c$. 4100-3900 cal. BP bracketed between two highstands dated to 4250-4100 and 3900-3750 cal. BP (Magny et al., 2007a). This appears to be in agreement with the picture given for the same time window by the Ledro lake-level record. 


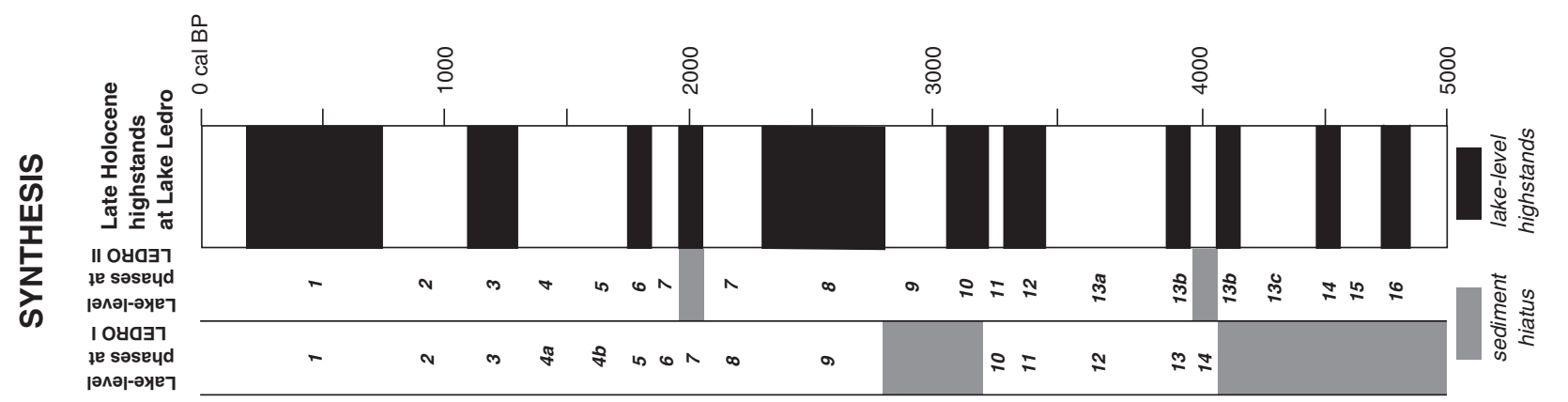

苛

댕

형

迹

ฐ

青
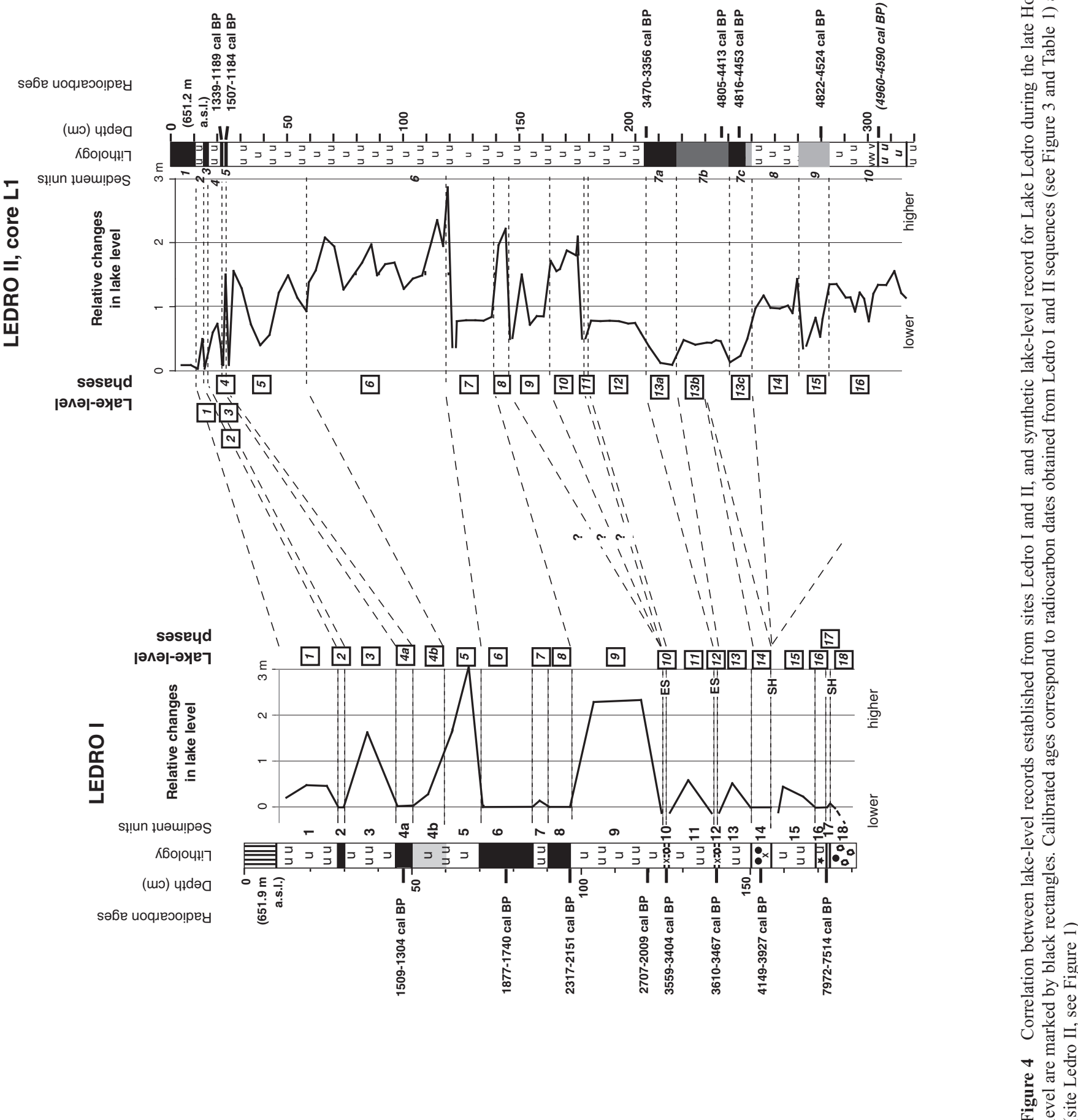

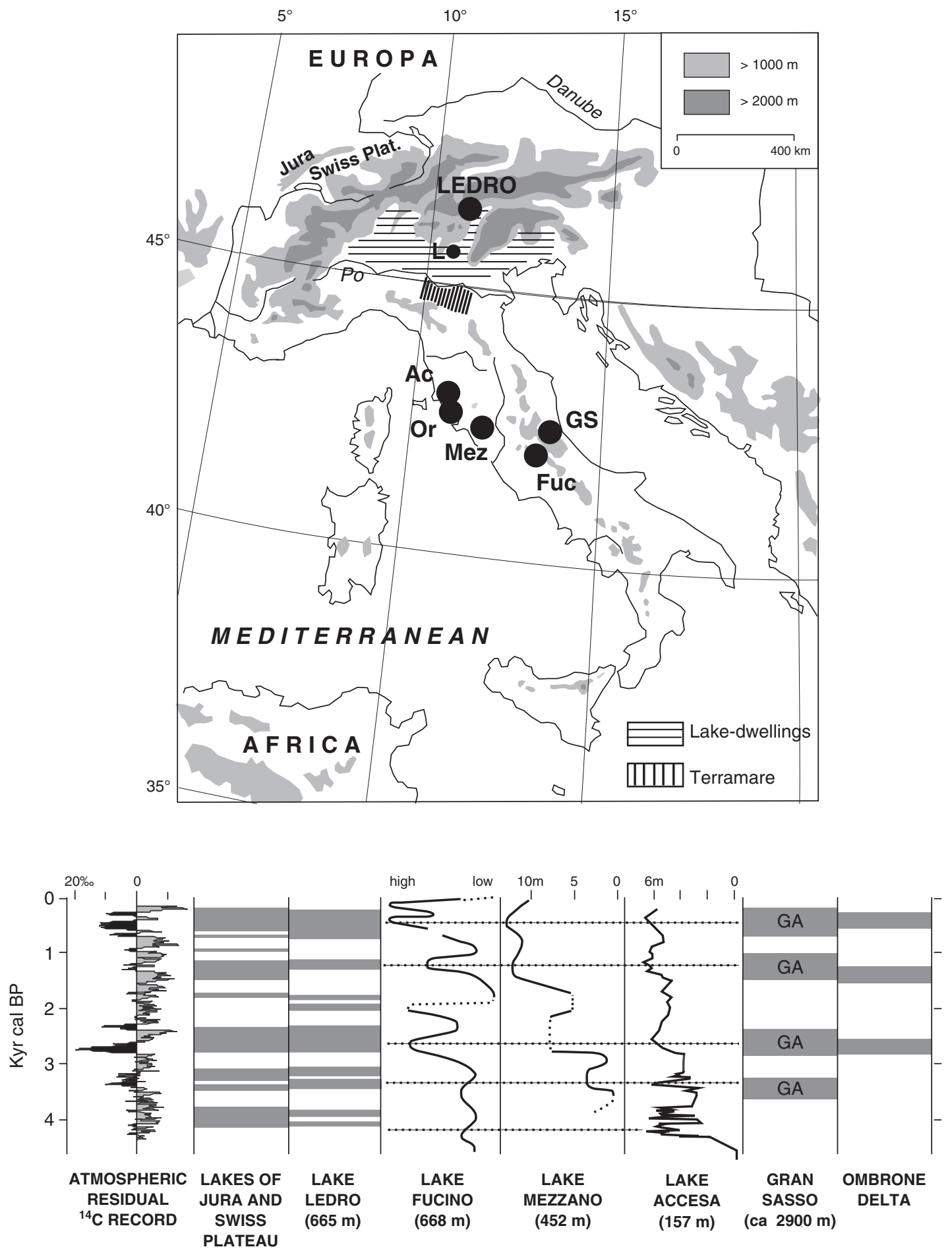

Figure 5 Comparison of the late-Holocene Ledro lake-level record (this study, see Figure 4) with (1) palaeohydrological data obtained in Italy at Fucino (Giraudi, 1998), Mezzano (Giraudi, 2004), Accesa (Magny et al., 2007a), and Ombrone river delta (Bellotti et al., 2004), and in west-central Europe north of the Alps (Magny, 2004, 2006), (2) cooling events on the higher Apennine massifs (Giraudi, 2005a, b), and (3) the atmospheric residual ${ }^{14} \mathrm{C}$ record (Stuiver et al., 1998). GA, glacier advance. Map in the upper panel: Ac, Lake Accesa; Fuc, Lake Fucino; GS, Gran Sasso; L, Lake Lucone; Mez, Lake Mezzano; Or, Ombrone river delta

Considered as a whole, the correlations observed in Figure 5 on a centennial-scale (1) between various palaeohydrological records in northern and central Italy, and (2) between lake-level highstands and glacier advances assumed to be driven by natural forcing before present-day global warming, support the hypothesis that changes in lake level shown in Figure 5 actually registered a climatic signal. In addition, correlations between lake-level records south and north of the Alps also suggest that over the last 4500 years northern and central Italy displayed a similar pattern of hydrological changes, with increasing humidity in response to Holocene cooling phases recognized in the North Atlantic area and to variations in solar activity (Bond et al., 2001; Magny et al., 2003; Blaauw et al., 2004).

Furthermore, on a millennial scale and in agreement with the three lake-level records established at Fucino, Mezzano and Accesa (Figure 5), the Ledro record (Figure 3, upper panel) gives evidence of a similar general trend characterized by an increase in lake level during the late Holocene. However, it is possible that 
Table 2 List for selected records of worldwide climate change at c. 3600-3300 cal. BP. The site numbers are those indicated in Figure 6

\begin{tabular}{|c|c|c|c|c|}
\hline Site number & Site & References & Age (cal. yr BP) & Climatic signal \\
\hline 1 & Lake Ledro, Trentino, Italy & This study & 3450 & wetter \\
\hline \multirow[t]{2}{*}{2} & Lake Accesa, Tuscany, Italy & Magny et al., 2007a & 3400 & wetter \\
\hline & Lago di Mezzano, Central Italy & Sadori et al., 2004 & 3400 & wetter \\
\hline 3 & Adriatic Sea, Mediterranean & Piva et al., 2008 & 3400 & cooler and wetter \\
\hline 4 & Rhone River delta, south France & Arnaud-Fassetta, 2004 & 3350 & wetter \\
\hline 5 & Loire River, central France & Wallinga, 2002 & $3200 \pm 100$ & wetter \\
\hline 6 & Jura and Pre-Alps (France), Swiss Plateau & Magny, 2004; Magny et al., 2009 & 3450 & cooler and wetter \\
\hline 7 & Lake Holzmaar, Germany & Baier et al., 2004 & $3660-3600$ & cooler \\
\hline 8 & Germany & Zolitschka et al., 2003 & $3500-3400$ & cooler and wetter \\
\hline 9 & southern Germany & Billamboz, 2003 & $3530-3470$ & cooler \\
\hline 10 & Kauner valley, Austria & Nicolussi et al., 2005 & 3400 & cooler \\
\hline 11 & Alps, Austria & Schmidt et al., 2007 & 3250 & wetter \\
\hline 12 & Swiss Plateau and Alps & Haas et al., 1998 & 3600 & cooler and wetter \\
\hline 13 & Poland rivers & Gregory et al., 2006 & 3500 & wetter \\
\hline 14 & Aegean Sea & Rohling et al., 2002 & 3500 & cooler \\
\hline 15 & Spain rivers & Gregory et al., 2006 & 3500 & wetter \\
\hline 16 & Lake Igelsjön, south Sweden & Hammarlund et al., 2003 & 3500 & wetter \\
\hline 17 & south Norway & Shakesby et al., 2007 & 3650 & cooler \\
\hline 18 & Lake Laihalampi, Finland & Heikkilä and Seppä, 2003 & 3500 & cooler \\
\hline 19 & Scandinavia, tree line & Berglund, 2003 & $3700-3600$ & cooler \\
\hline 20 & Kola Peninsula, Russia & Boettger et al., 2003 & 3500 & cooler \\
\hline 21 & Norwegian Sea & Calvo et al., 2002 & 3500 & cooler \\
\hline 22 & Norwegian Sea & Birks and Koç, 2002 & 3500 & cooler \\
\hline 23 & Lake Vankavad, Russia & Sarmaja-Korjonen et al., 2003 & 3620 & wetter \\
\hline 24 & Lake Sihailongwan, northeastern China & Schettler et al., 2006 & 3600 & drier \\
\hline 25 & East Asia & Porter and Weijian, 2007 & 3290 & colder and drier \\
\hline 26 & Mount Everest, Himalaya glaciers & Finkel et al., 2003 & 3600 & cooler \\
\hline 27 & Gujarat, India & Prasad et al., 2007 & 3400 & drier \\
\hline 28 & Lake Masoko, Tanzania & Vincens et al., 2003 & 3450 & drier \\
\hline 29 & Cold Air Cave, south Africa & Lee-Thorp et al., 2001 & 3500 & colder and drier \\
\hline 30 & Australia & Haberle and David, 2004 & 3500 & drier \\
\hline 31 & EPICA, Antarctica & Masson-Delmotte et al., 2004 & 3500 & colder \\
\hline 32 & Signy Island, maritime Antarctica & Noon et al., 2003 & 3500 & cooler and drier \\
\hline 33 & Southern Andes, Argentina & Wenzens, 1999 & 3600 & cooler \\
\hline 34 & Patagonia & Glasser et al., 2004 & 3600 & cooler \\
\hline 35 & Gulf of California & Pérez-Cruz, 2006 & 3360 & cooler \\
\hline 36 & Hemlock, British Columbia & Hallett et al., 2003 & 3500 & cooler and wetter \\
\hline 37 & Vancouver Island & Patterson et al., 2005 & 3400 & wetter \\
\hline 38 & Skinny Lake, British Columbia & Spooner et al., 2002 & 3500 & cooler \\
\hline 39 & Southern Alaska & Barclay et al., 2006 & 3500 & cooler \\
\hline 40 & White Lake & Li et al., 2007 & 3350 & drier \\
\hline 41 & Boothia Peninsula, Canada & Zabenskie and Gayewski, 2007 & 3600 & cooler \\
\hline 42 & West Greenland & Lloyd et al., 2007 & 3500 & cooler \\
\hline 43 & GISP2 Na+ & Mayewski et al., 1997 & 3500 & deeper Iceland Low \\
\hline 44 & GISP2 K+ & Meeker and Mayewski, 2002 & 3500 & Stronger Siberian High \\
\hline 45 & North Iceland & Kirkbride et al., 2006 & 3500 & wetter \\
\hline 46 & North Icelandic shelf & Jiang et al., 2002 & 3600 & cooler \\
\hline 47 & Temple Hill moss, Scotland & Langdon et al., 2003 & 3400 & wetter \\
\hline 48 & Loch Sunart, Scotland & Mokeddem et al., 2007 & 3500 & cooler \\
\hline 49 & Britain, rivers & Macklin and Lewin, 2002 & 3550 & wetter \\
\hline 50 & Walton moss, England & Hughes et al., 2000 & 3500 & wetter \\
\hline 51 & Azores, North Atlantic & Björck et al., 2006 & $3400-3300$ & cooler and drier \\
\hline 52 & North Atlantic ocean & Bond et al., 2001 & 3500 & cooler \\
\hline 53 & North Atlantic ocean & Hall et al., 2004 & 3600 & cooler \\
\hline
\end{tabular}

forest clearance (as illustrated by pollen data in Figure 2 for Lake Ledro) could have amplified the response of water-tables to wetter climatic conditions by increasing runoff and consecutive colluvial accumulation around the lake outlets, particularly since the Bronze Age. Using palaeolimnological data, Filippi et al. (2007b) also hypothesized that, at Lake Nero (Trentino) located at an elevation of $2233 \mathrm{~m}$ a.s.l., relatively low lake-level conditions prevailed during the first part of the Holocene (up to $c .8000$ cal. BP). Sediment hiatuses recognised by Lona (1970) from the pollen stratigraphy of mires in northern Italy provide additional support to the above observations. It is also noteworthy that a continuous sedimentation on the site of Ledro I initiated only after c. $2700 \mathrm{cal}$. $\mathrm{BP}$, ie, during a time of a major climate reversal at the subBoreal-sub-Atlantic transition (van Geel et al., 1996).

Regarding the question of continuity of Middle Bronze Age lake- and wetland-dwellings (3600-3300 cal. BP) and their flourishing development north of the River Po, or the expansion of Terramare in the southern areas of the Po plain between 3550 and $3100 \mathrm{cal} \mathrm{BP}$, one observes that these phenomena contrast with the general abandonment of the lake shores observed north of the Alps at the same time (see Figure 7). The lake-level record established at Ledro in northern Italy, like those reconstructed for Lakes 


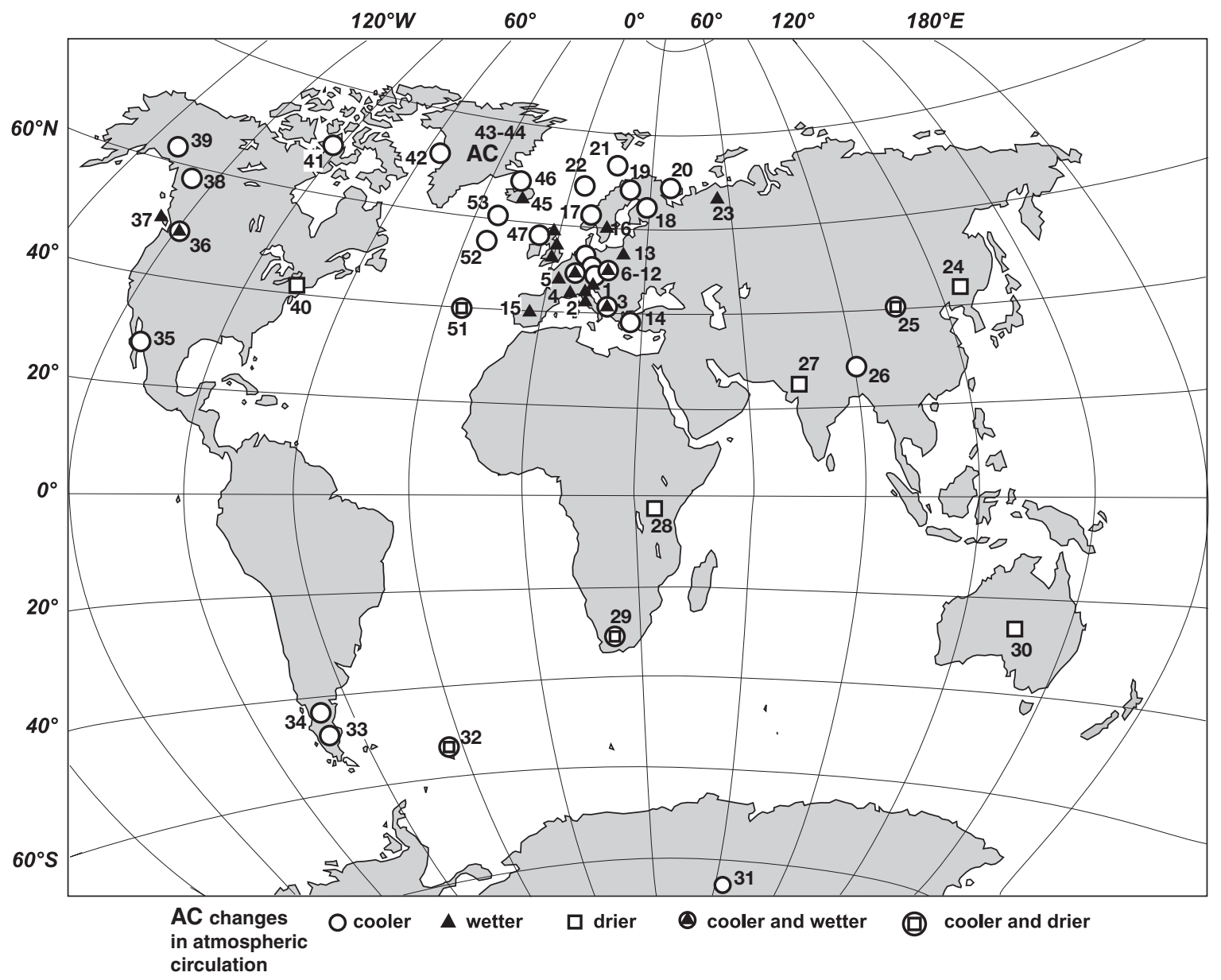

Figure 6 Widespread climate change at c. 3600-3300 cal. BP as reflected by multiproxy records listed in Table 2

Fucino, Mezzano and Accesa in central Italy (Figure 5), suggests that the singularity of the Italian humid settlements during the Middle and Recent Bronze Ages did not result from a peculiar climatic history: the transition from phases 13 to 12 at Ledro II dated to $c .3400$ cal. BP coincides with a rise in lake level well marked by the cessation of peat formation (sediment unit 7) and its overlying by carbonate deposits (sediment unit 6). Furthermore, the climate reversal dated to c. 3600-3400 cal. BP and marked by higher lake-level conditions in northern and central Italy, as well north of the Alps, appears to correspond to a worldwide event observed in both hemispheres as illustrated by data listed in Table 2 and presented in Figure 6. Its synchronicity with a peak in the residual atmospheric ${ }^{14} \mathrm{C}$ content (Stuiver et al., 1998) and in the Greenland ${ }^{10} \mathrm{Be}$ record (Bond et al., 2001) suggests that it was associated with a decrease in solar activity. As shown by Figure 6, this climate reversal corresponds at mid-European latitudes to temperature cooling and increasing humidity resulting in higher lake levels, increasing river discharge, as well as glacier advances and tree limit decline in the Alpine area. Quantitative estimates of seasonal changes in west-central Europe show increasing annual precipitation by c. $70-100 \mathrm{~mm}$ (more particularly during the summer season) and decreasing mean annual temperature by $c .0 .7^{\circ} \mathrm{C}$ (Magny et al., 2009).

Regarding the Bronze Age settlements of Lake Ledro, the Ledro II pollen diagram (Figure 2) suggests a relative decrease in the human impact at the transition between sediment units 7 and 6 , ie, at c. $3400 \mathrm{cal}$. BP. However, the two pollen records obtained by Beug (1964) from the same site, although with a lower temporal resolution, invite caution before concluding too hastily concerning a possible influence of climate on Bronze Age settlements. First,
Beug's data clearly show that the period of strong human impact began earlier than the deposition of peaty sediment unit 7 . Second, they give evidence that the maximum of human impact on the vegetation cover does not coincide with the top of sediment unit 7, but with the basal part of carbonate sediment unit 6 , ie, during a period of higher lake-level conditions. This indicates that the development of Bronze Age lake-dwellings cannot be explained only by climatic determinism. Further palaeoenvironmental and palaeoclimatic investigations, particularly in the outlet area where the most extensive archaeological site has been found, and additional core studies from the profundal zone of Lake Ledro, are still needed to obtain a more precise picture of possible past interactions between environment, climate and human settlement around Lake Ledro.

More generally speaking, on a regional scale, northern Italy was characterized by flourishing and lasting lake-dwelling settlements throughout the Bronze Age from c. 4050 to $c$. 3150/3050 cal. BP (Martinelli, 1996; Guidi and Bellintani, 1996; De Marinis et al., 2005). Maximal frequency of Bronze Age lake-dwellings spans the period 3550-3300/3250 cal. BP (Figure 7). In addition, on the Po plain, the development of Terramare covers the period 3550-3100 cal. BP with a maximum at c. 3400-3350 cal. BP (Cremaschi et al., 2006). Regarding the chronology, the beginning of the climatic reversal reflected at Ledro II by the transition from sediment units 7 to 6 , is radiocarbon dated to c. 3400 cal. BP. Owing to lack of radiocarbon dates from sediment unit 6 , it is not possible to establish the end of this high lake-level phase at Ledro. However, lithological changes observed in a sediment sequence at Lake Lucone, southwest of Lake Garda (Figure 5), give evidence of a lake-level lowering at c. $3050 \mathrm{cal}$. BP (Valsecchi et al., 2006). 


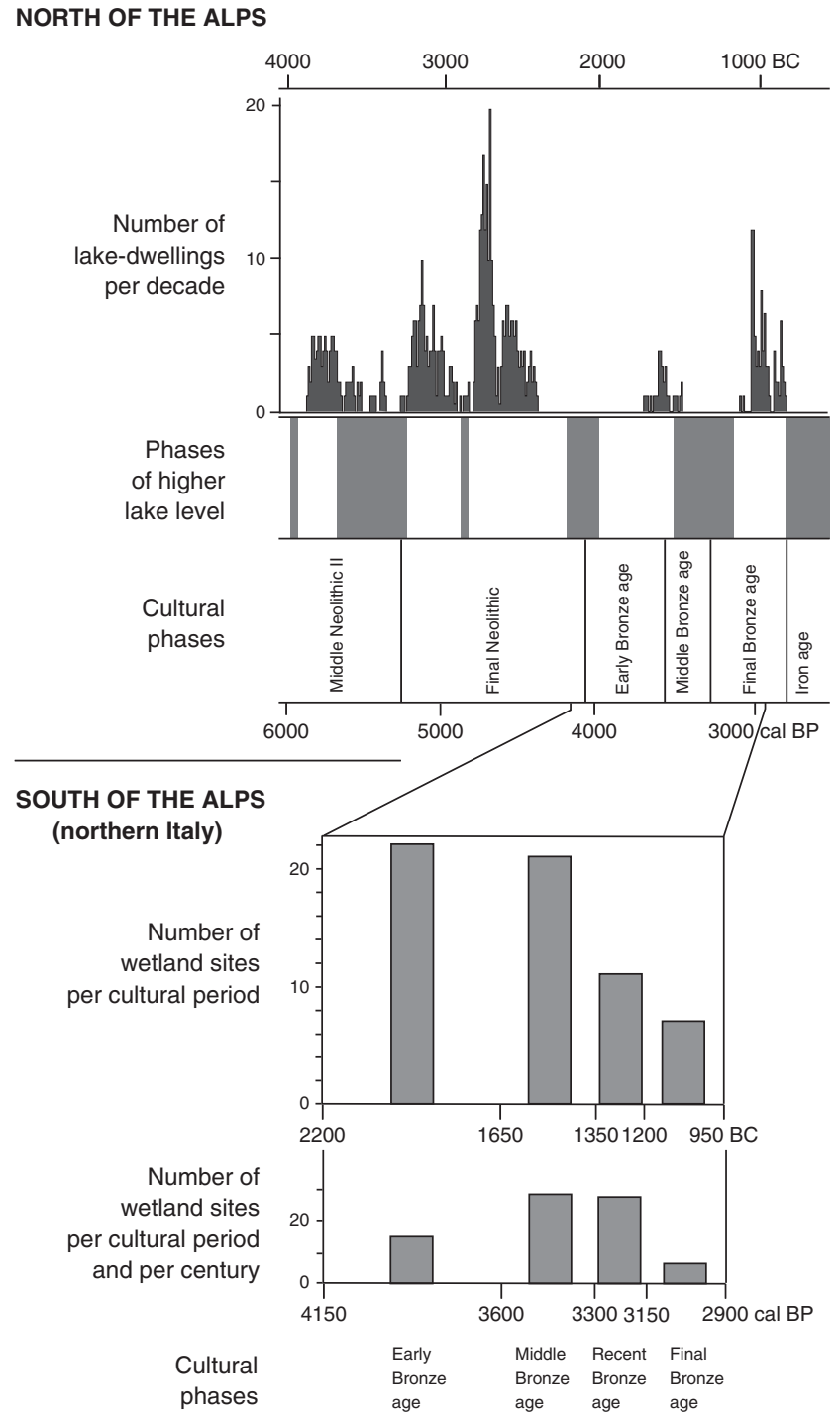

Figure 7 Frequency of lake-dwellings per cultural phases north and south of the Alps. Upper panel: Neolithic and Bronze age lakedwellings in eastern France and on the Swiss Plateau (Magny, 2004). Lower panel: frequency of Bronze Age lake-dwellings in northern Italy as estimated from archaeological remains found in wetland areas (Guidi and Bellintani, 1996). Note that north of the Alps, a general abandonment of Bronze Age lake-dwellings during the climate reversal dated to $c$. 3500-3100 cal. BP is observed. This contrasts with the continuity and maximal frequency of wetland sites in northern Italy during the Middle and Recent Bronze Ages

This is in agreement with the age of climatic drying dated to c. 3100 cal. BP from geoarchaeological observations at the Terramare of Poviglio on the Po plain (Cremaschi et al., 2006). This regional northern Italy chronology also appears to be in agreement with that established at Lake Accesa in central Italy (Magny et al., 2007a), and to be close to that established north of the Alps in west-central Europe where the beginning of the climate reversal is tree-ring dated to $3460 \mathrm{cal}$. BP and its end to c. 3150-3100 cal. BP on the basis of tree-ring and radiocarbon dates (Magny et al., 2007b). Finally, the lake-level records from Ledro (this study) and Accesa (Magny et al., 2007a) as well as from west-central Europe (Magny, 2006; Magny et al., 2007b) show that, in fact, this phase of climate reversal was divided into distinct successive events (Figure 5).

Thus south of the Alps, despite a climate characterized by increasing moisture after $3400 \mathrm{cal}$. BP, Bronze Age settlements remained in humid areas of lake shores and in the Po plain, while drier climatic conditions prevailing after $c .3100 \mathrm{cal}$. BP appear to be synchronous with a general crisis of lake and wetland villages, and an abrupt end of Terramare. This flourishing of Bronze Age settlements in humid areas during a period marked by wetter climatic conditions probably suggests, as a working hypothesis, a peculiar socio-economic organization of Bronze Age societies in northern Italy. Alternatively, these Bronze Age societies may have collected more wild food plants from the surrounding woodland as shown from the palaeoethnobotanical material within the cultural layers of the Ledro settlement (Pinton and Carrara, 2007) or may have used additional food and fodder resources in case of losses or reduced crop yield as shown for the nearby Early to Mid-Bronze Age site of Fiavè-Carera for times of shortage (Karg, 1998; Haas et al., 1998a). In the specific case of Terramare, Cremaschi et al. (2006) have shown how their development was associated with original management of water to the fields through a network of irrigation ditches. Finally, far from a simplistic deterministic interpretation, the history of Bronze Age societies in northern Italy calls for a deeper knowledge of their social organization and subsistence strategy (control of resources, production of economic surplus in response to growing population) before a more comprehensive view of their possible interactions with environmental and climate conditions can be drawn.

\section{Acknowledgements}

Financial support for this study was provided by the European Union (program ACCROTELM supervised by Professor F. Chambers, EVK2-2002-00166), the French CNRS (programme ECLIPSE), the French ANR (project LAMA supervised by M. Magny and N. Combourieu-Nebout, MSHE Ledoux-USR 3124, Besançon), and the Ecole Française de Rome. The manuscript benefitted greatly from comments by L. Sadori and B. Zolitschka. The authors also express their sincere thanks to M. L. Filippi and S. Frisia for their help in initiating palaeoenvironmental studies at Lake Ledro, $\mathrm{N}$. Moussard for his help with the fieldwork and J. Olsen for his help with the English language.

\section{References}

Arnaud-Fassetta, G. 2002: Geomorphological records of a 'flooddominated regime' in the Rhöne Delta (France) between the 1st century $\mathrm{BC}$ and the second century $\mathrm{AD}$. What correlations with the catchment paleohydrology? Geodinamica Acta 15, 79-92.

2004: The upper Rhône delta sedimentary record in the 'ArlesPiton' core: analysis of delta-plain subenvironments, avulsion frequency, aggradation rate and origin of sediment yield. Geografiska Annaler A - Physical Geography 86, 367-83.

Baier, J., Lücke, A., Negendank, J.F.W., Schleser, G.H. and Zolitschka, B. 2004: Diatom and geochemical evidence of mid- to late Holocene climatic changes at Lake Holzmaar, West-Eifel (Germany). Quaternary International 113, 81-96.

Barclay, D.J., Barclay, J.L., Calkin, P.E. and Wiles, G.C. 2006: A revised and extended Holocene glacial history of Icy Bay, southern Alaska, U.S.A. Arctic, Antarctic, and Alpine Research 38, 153-62.

Battaglia, R. 1943: La palafitta del Lago di Ledro nel Trentino. Memoria del Museo di Storia Naturale della Venezia Tridentina 7, 1-63. Bellotti, P., Caputo, C., Davoli, L., Evangelista, S., Garzanti, E., Pugliese, F. and Valeri, P. 2004: Morpho-sedimentary characteristics and Holocene evolution of the emergent part of the Ombrone River delta (southern Tuscany). Geomorphology 61, 71-90.

Benvenuti, M., Mariotti-Lippi, M., Pallechi, P. and Sagri, M. 2006: Late-Holocene catastrophic floods in the terminal Arno river (Pisa, Central Italy) from the story of a Roman riverine harbour. The Holocene 16, 863-76.

Berglund, B. 2003: Human impact and climate changes - synchronous events and a causal link? Quaternary International 105, 7-12. 
Beug, H.J. 1964: Untersuchungen zur spätglazialen Vegetationsgeschichte im Gardaseegebiet unter besonderer Berücksichtigung der mediterranen Arten. Flora 154, 401-44.

Billamboz, A. 2003: Tree rings and wetland occupation in southwest Germany between 2000 and 500 BC: dendroarchaeology beyond dating in tribute to F. H. Schweingruber. Tree-Ring Research 59, 37-49. Birks, C. and Koç, N. 2002: A high-resolution diatom record of lateQuaternary sea-surface temperatures and oceanographic conditions from the eastern Norwegian Sea. Boreas 31, 323-44.

Björck, S., Rittenour, T., Rosen, P., França, Z., Möller, P., Snowball, I., Wastegard, S., Bennike, O. and Kromer, B. 2006: A Holocene lacustrine record in the central North Atlantic: proxies for volcanic activity, short-term NAO mode variability, and long-term precipitation changes. Quaternary Science Reviews 25, 9-32.

Blaauw, M., van Geel, B. and van der Plicht, J. 2004: Solar forcing of climatic change during the mid-Holocene: indications from raised bogs in The Netherlands. The Holocene 14, 35-44.

Boettger, T., Hiller, A. and Kremenetski, K. 2003: Mid-Holocene warming in the northwest Kola Peninsula, Russia: northern pine-limit movement and stable isotope evidence. The Holocene 13, 403-10.

Bond, G., Kromer, B., Beer, J., Muscheler, R., Evans, M.N., Showers, W., Hoffmann, S., Lotti-Bond, R., Hajdas, I. and Bonani, G. 2001: Persistent solar influence on North Atlantic climate during the Holocene. Science 294, 2130-36.

Calvo, E., Grimalt, J. and Jansen, E. 2002: High resolution Uk/37 sea surface temperature reconstruction in the Norwegian sea during the Holocene. Quaternary Science Reviews 21, 1385-94.

Camuflo, D. and Enzi, S. 1994: Cambiamenti climatici negli ultimi 2000 anni. Il Quaternario 7, 257-66.

Cortesi, C. and Leonardi, G. 2002: Nuovi dati radiometrici dalla palafitta di Molina di Ledro (scavi 1980, 1983). Istituto Italiano di Preistoria e Protohistoria 33, 369-76.

Cremaschi, M., Pizzi, C. and Valsecchi, V. 2006: Water management and land use in the terramare and a possible climatic co-factor in their abandonment: the case suty of the terramara of Poviglio Santa Rosa (northern Italy). Quaternary International 151, 87-98.

Dal Ri, L. and Piva, G. 1987: Ledro B: una stazione del primo medioevo a volta di besta sul lago di Ledro nel Trentino. Atti della Accademia Roveretana Degli Agiati 236, 265-347.

De Marinis, R.C., Ravazzi, C., Arpenti, E., Deaddis, M., Perego, R. and Rapi, M. 2005: Lavagnone (Desenzano del Garda): new excavations and paleoecology of a Bronze Age pile dwelling site in northern Italy. In Della Casa, P. and Trachsel, M., editors, WES'O4, Wetland Economies and Societies. Collectio Archaeologica 3, 221-32.

Digerfeldt, G. 1988: Reconstruction and regional correlation of Holocene lake-level fluctuations in lake Bysjön, South Sweden. Boreas 17, 165-82.

Drysdale, R., Zanchetta, G., Hellstrom, J., Maas, R., Fallick, A. Pickett, M., Cartwright, I. and Piccini, L. 2006: Late Holocene drought responsible for the collapse of Old World civilizations is recorded in an Italian cave flowstone. Geology 34, 101-104.

Faegri, K. and Iversen, J. 1989: Textbook of pollen analysis. Fourth edition. John Wiley \& Sons.

Filippi, M.L., Heiri, O., Arpenti, E., Angeli, N., Bortolotti, M., Lotter, A.F. and Van Der Borg, K. 2007a: Evoluzione paleoambientale dal Tardoglaciale a oggi ricostruita attraverso lo studio dei sedimenti del Lago di Lavarone (Altopiano di Folgaria e Lavarone, Trentino). Studi Trentini Di Scienze Naturali Acta Geologica 82, 279-98.

_ 2007b: Studio paleolimnologico del Lago Nero di Cornisello (Parco Naturale Adamello-Brenta, Trentino). Studi Trentini Di Scienze Naturali Acta Geologica 82, 261-78.

Finkel, R.C., Owen, L.A., Barnard, P.L. and Caffee, M.W. 2003: Beryllium-10 dating of Mount Everest moraines indicates a strong monsoon influence and glacial synchroneity throughout the Himalya. Geology 31, 561-64.

Giraudi, C. 1998: Late Pleistocene and Holocene lake-level variations in Fucino Lake (Abruzzo, central Italy) inferred from geological, archaeological and historical data. In Harrison, S.P., Frenzel, B., Huckried, U. and Weiss, M., editors, Palaeohydrology as reflected in lake-level changes as climatic evidence for Holocene times. Paläoklimaforschung 25, 1-17.
2004: Le oscillazioni di livello del Lago di Mezzano (ValentinoVT): variazioni climatiche e interventi antropici. Il Quaternario 17, 221-30.

2005a: Middle to Late Holocene glacial variations, periglacial processes and alluvial sedimentation on the higher Apennine massifs (Italy). Quaternary Research 64, 176-84.

2005b: Late-Holocene alluvial events in the Central Apennines, Italy. The Holocene 15, 768-73.

Glasser, N.F., Harrison, S., Winchester, V. and Aniya, M. 2004: Late Pleistocene and Holocene palaeoclimate and glacier fluctuations in patagonia. Global and Planetary Change 43, 79-101.

Gregory, K.J., Benito, G., Dikau, R., Golosov, V., Johnstone, E.C., Jones, J.A.A., Macklin, M.G., Parsons, A.J., Passmore, D.G., Poesen, J., Soja, R., Starkel, L., Thorndycraft, V.R. and Walling, D.E. 2006: Past hydrological events and global change. Hydrological Processes 20, 199-204.

Guidi, C. and Bellintani, P. 1996: Gli abitati 'palafitticoli' dell'Italia settentrionale. Origini, Preistoria e protostoria delle civilta antiche $20,165-231$.

Haas, J.N., Karg, S. and Rasmussen, P. 1998a: Beech leaves and twigs used as winter fodder: examples from historic and prehistoric times. In Charles, M., Halstead, P. and Jones, G., editors, Fodder: archaeological, historical and ethnographic studies. Environmental Archaeology 1, 81-86.

Haas, J.N., Richoz, I., Tinner, W. and Wick, L. 1998b: Synchronous Holocene climatic oscillations recorded on the Swiss Plateau and at timberline in the Alps. The Holocene 8, 301-304.

Haberle, S.G. and David, B. 2004: Climates of change: human dimensions of Holocene environmental change in low latitudes of the PEPII transect. Quaternary International 118-119, 165-79.

Hall, I.R., Bianchi, G.G. and Evans, J.R. 2004: Centennial to millennial scale Holocene climate-deep water linkage in the North Atlantic. Quaternary Science Reviews 23, 1529-36.

Hallett, D.J., Lepofsky, D.S., Mathewes, R.W. and Lertzman, K.P. 2003: 11000 years of fire history and climate in the mountain hemlock rain forests of southwestern British Columbia based on sedimentary charcoal. Canadian Journal of Forest Research 33, 292-312.

Hammarlund, D., Björck, S., Buchard, B., Israelson, C. and Thomsen, T. 2003: Rapid hydrological changes during the Holocene revealed by stable isotope records of lacustrine carbonates from Lake Igelsjön, southern Sweden. Quaternary Science Reviews 22, $353-70$.

Heikkilä, M. and Seppä, H. 2003: A 11000 yr palaeotemperature reconstruction from the southern boreal zone in Finland. Quaternary Science Reviews 22, 541-54.

Hughes, P.D.M., Mauquoy, D., Barber, K.E. and Langdon, P.G. 2000: Mire-development pathways and palaeoclimatic records from a full Holocene peat archive at Walton Moss, Cumbria, England. The Holocene 10, 465-79.

Jiang, H., Seidenkranz, M.-S., Knudsen, K.L. and Eiriksson, J. 2002: Late-Holocene summer sea-surface remperatures based on a diatom record from the north Icelandic shelf. The Holocene 12, $137-47$.

Karg, S. 1998: Winter- and spring-foddering of sheep/goat in the Bronze Age site of Fiavè-Carera, Northern Italy. In Charles, M., Halstead, P. and Jones, G., editors, Fodder: srchaeological, historical and ethnographic studies. Environmental Archaeology 1, 87-94.

Kirkbride, M., Dugmore, A.J. and Brazier, V. 2006: Radiocarbon dating of mid-Holocene megaflood deposits in the Jökulsà à Fjöllum, north Iceland. The Holocene 16, 605-609.

Langdon, P.G., Barber, K.E. and Hughes, P.D.M. 2003: A 7500year peat-based palaeoclimatic reconstruction and evidence for an 1100-year cyclicity in bog surface wetness from Temple Hill Moss, Pentland Hills, southeast Scotalnd. Quaternary Science Reviews 22, 259-74.

Lee-Thorp, J.A., Holmgren, K., Lauritzen, S.E., Linge, H., Moberg, A., Partridge, T.C., Stevenson, C. and Tyson, P.D. 2001: Rapid climate shifts in the southern African interior throughout the mid to late Holocene. Geophysical Research Letters 28, 4507-10.

Leonardi, G., Bianchin, E., Balista, C. and Stabile, G. 1979: Ripresa degli scavi nella palafitta di Molina di Ledro. Scavi 1980 Nota preliminare. Preistoria Alpina 15, 39-55. 
Li, Y.X., Yu, Z. and Kodama, K.P. 2007: Sensitive moisture response to Holocene millennial-scale climate variations in the Mid-Atlantic region, USA. The Holocene 17, 3-8.

Lloyd, J.M., Kuijpers, A., Long, A., Moros, M. and Park, L.A. 2007: Foraminiferal reconstruction of mid- to late-Holocene ocean circulation and climate variability in Disko Bugt, West Greenland. The Holocene 17, 1079-91.

Lona, F. 1970: Evidence of a 'Hiatus borealis' in Olocenic deposits of northern Italy. Mitteilungen Ostalpinen-dinarischen pflanzensoziologischen Arbeitsgemeinschaft 10, 53-54.

Macklin, M.G. and Lewin, J. 2002: River sediments, great floods and centennial-scale Holocene climate change. Journal of Quaternary Science 18, 101-105.

Magny, M. 1993: Climatic contribution can provide an answer for prehistoric lake dwellings. Compte-Rendus Académie des Sciences Paris 316, 1619-25.

_ 1998: Reconstruction of Holocene lake-level changes in the Jura (France): methods and results. Paläoklimaforschung 25, 67-85.

- 2004: Holocene climatic variability as reflected by midEuropean lake-level fluctuations, and its probable impact on prehistoric human settlements. Quaternary International 113, 65-79.

2006: Holocene fluctuations of lake levels in west-central Europe: methods of reconstruction, regional pattern, palaeoclimatic significance and forcing factors. In Elias, S.A., editor, Encyclopedia of Quaternary geology. Encyclopedia of Quaternary Science, Elsevier, 1389-99.

Magny, M. and Peyron, O. 2008: Variations climatiques et histoire des sociétés à l'Age du Bronze au nord et au sud des Alpes. In Guilaine, J., editor, Villes, villages, campagnes de l'Age du Bronze. Editions Errance, 159-76.

Magny, M., Bégeot, C., Guiot, J. and Peyron, O. 2003: Contrasting patterns of hydrological changes in Europe in response to Holocene climate cooling phases. Quaternary Science Reviews 22, 1589-96.

Magny, M., de Beaulieu, J.L., Drescher-Schneider, R., Vannière, B., Walter-Simonnet, A.V., Miras, Y., Millet, L., Bossuet, G., Peyron, O., Brugiapaglia, E. and Leroux, A. 2007a: Holocene climate changes in the central Mediterranean as recorded by lake-level fluctuations at Lake Accesa (Tuscany, Italy). Quaternary Science Reviews 26, 1736-58.

Magny, M., Billaud, Y., Bossuet, G., Gauthier, E., Marguet, A., Mouthon, J., Richard, H. and Vannière, B. 2007b: Variations du climat pendant l'Age du Bronze au centre ouest de l'Europe: vers l'établissement d'une chronologie à haute résolution. In Richard, $\mathrm{H}$., Magny, M. and Mordant, C., editors, Environnements et cultures à l'âge du Bronze en Erurope occidentale. CTHS Editions, 13-28.

Magny, M., Peyron, O., Gauthier, E., Rouèche, H., Bordon, A., Billaud, Y., Chapron, E., Marguet, A., Pétrequin, P. and Vannière, B. 2009: Quantitative reconstruction of climatic variations during the Bronze and early Iron ages based on pollen and lake-level datat in the NW Alps, France. Quaternary International in press.

Marchant, R. and Hooghiemstra, H. 2004: Rapid environmental change in African and South American tropics around 4000 years before present: a review. Earth Science Reviews 66, 217-60.

Martinelli, N. 1996: Datazioni dendrocronologiche per l'età del Bronzo dell'area Alpina. Acta Archaeologica 67, 315-26.

2005: Dendrocronologia e Archeologia: situazione e prospettive della ricerca in Italia. British Archaeological Reports International Serie 1452, 437-48.

Masson-Delmotte, V., Stenni, B. and Jouzel, J. 2004: Common millennial-scale variability of Antarctic and Southern Ocean temperatures during the past 5000 years reconstructed from the EPICA Dome C core. The Holocene 14, 145-51.

Mayewski, P.A., Meeker, L.D., Twickler, M.S., Whitlow, S., Yang, Q., Lyons, W.B. and Prentice, M. 1997: Major features and forcing of high-latitude northern hemisphere atmospheric circulation using a 110000 year long glaciochemichal series. Journal of Geophysical Research 102, 26 345-66.

Meeker, L.D. and Mayewski, P.A. 2002: A 1400-year high-resolution record of atmospheric circulation over the North Atlantic and Asia. The Holocene 12, 257-66.

Mercuri, A.M., Accorsi, C.A. and Mazzanti, M.B. 2002: The long history of Cannabis and its cultivation by the Romans in central Italy, shown by pollen records from Lago Albano and Lago di Nemi. Vegetation History and Archaeobotany 11, 263-76.

Mitchum, R.M., Vail, J.R. and Thompson, S. 1977: The depositional sequence as a basic unit for stratigraphic analysis. American Association Geolological Bulletin, Memory 26, 53-62.

Mokkedem, Z., Baltzer, A., Clet-Pellerin, M., Walter-Simonnet, A.V., Bates, R., Balut, Y. and Bonnot-Courtois, C. 2007 Fluctuations climatiques enregistrées depuis 20000 ans dans le remplisssage sédimentaire du loch Sunart (Nord-Ouest de l'Ecosse). Compte-Rendu Géoscience 339, 150-60.

Mouthon, J. 1984: Les mollusques. In Service Régional d'Aménagement des Eaux, editor, Les lacs de Clairvaux, Monographies écologiques. SRAE Report, 67-75.

Nicolussi, K., Kaufmann, M., Patzelt, G., van der Plicht, J. and Thurner, A. 2005: Holocene tree-line variability in the Kauner valley, central eastern Alps, indicated by dendrochronological analysis of living trees and subfossil logs. Vegetation History and Archaeobotany $14,221-34$

Noon, P.E., Leng, M.J. and Jones, V.J. 2003: Oxygen-isotope $\left(\mathrm{d}^{18} \mathrm{O}\right)$ evidence of Holocene hydrological changes at Signy Island, maritime Antarctica. The Holocene 13, 251-63.

Patterson, R.T., Prokoph, A., Kumar, A., Chang, A.S. and Roe, H.M. 2005: Late Holocene variability in pelagic fish scales and dinoflagellate cysts along the west coast of Vancouver Island, NE Pacific Ocean. Marine Micropaleontology 55, 183-204.

Pérez-Cruz, L. 2006: Climate and ocean variability during the middle and late Holocene recorded in laminated sediments from Alfonso Basin, Gulf of California, Mexico. Quaternary Research 65, 401-10. Perini, R. 1994: Scavi archeologici nella zona palafitticola di FiaveCarera, Parte III. Patrimonio storico e artistico del trentino 10. Servizio Beni Culturali della Provincia Autonoma di Trento.

Pinton, V. and Carrara, N. 2007: La collezione della palafitta di Ledro del Museo di Antropologia dell'Università di Padova: ricostruzione del paleoambiente. Annali dell'Università degli Studi di Ferrara Museologia Scientifica e Naturalistica - Special Volume 2007, 11-14.

Piva, A., Asioli, A., Trincardi, F., Schneider, R.R. and Vigliotti, L. 2008: Late-Holocene climate variability in the Adriatic Sea (Central Mediterranean). The Holocene 18, 153-67.

Porter, S.C. and Weijian, Z. 2007: Synchronism of Holocene East Asian monsoon variations and North Atlantic drift-ice tracers. Quaternary Research 65, 443-49.

Prasad, V., Phartiyal, B. and Sharma, A. 2007: Evidence of enhanced winter precipitation and the prevalence of a cool and dry climate during the mid to late Holocene in mainland Gujarat, India. The Holocene 17, 889-96.

Rageth, J. 1974: Der Lago di Ledro im Trentino und seine Beziehungen zu den alpinen und mitteleuropäischen Kulturen. Bericht der Romisch-Germanischen Kommission 55, 73-260.

Reille, M. 1992-1998: Pollen et spores d'Europe et d'Afrique du nord. Laboratoire de Botanique Historique et Palynologie, Université d'Aix-Marseille.

Rohling, E.J., Mayewski, P.A., Hayes, A., Abu-Zied, R.H. and Casford, J.S.L. 2002: Holocene atmosphere-ocean interactions: records from Greenland and Aegean Sea. Climate Dynamics 18, 573-92.

Sadori, L., Giraudi, C., Petitti, P. and Ramrath, A. 2004: Human impact at Lago di Mezzano (central Italy) during the Bronze Age: a multidisciplinary approach. Quaternary International 113, 5-17.

Sarmaja-Korjonen, K., Kultti, S., Solovieva, N. and Väliranta, M. 2003: Mid-Holocene palaeoclimatic and palaeohydrological conditions in northeastern European Russia: a multi-proxy study of Lake Vankavad. Journal of Paleolimnology 30, 415-26.

Schettler, G., Liu, Q., Mingram, J., Stebich, M. and Dulski, P. 2006: East-Asian monsoon variability between 15000 and $2000 \mathrm{cal} \mathrm{yr}$ BP recorded in varved sediments of Lake Sihailongwan (northeastern China, Long Gang volcanic field). The Holocene 16, 1043-57.

Schmidt, R., Kamekik, C. and Roth, M. 2007: Siliceous algae-based seasonal temperature inference and indicator pollen tracking ca 4000 years of climate/land use dependency in the southern Austrian Alps. Journal of Paleolimnology 38, 541-54.

Shakesby, R.A., Smith, J.G., Matthews, J.A., Winkler, S., Dresser, P.Q., Bakke, J., Dahl, S.O., Lie, O. and Nesje, A. 2007: Reconstruction of glacier Holocene history from distal sources: 
glaciofluvial streal-bank mires and a glaciolacustrine sediment core near Sota Saeter, Breheimen, Norway. The Holocene 17, 729-45.

Spooner, I.S., Mazzuchi, D., Osborn, G., Gilbert, R. and Larocque, I. 2002: A multi-proxy Holocene record of environmental change from the sediments of Skinny Lake, Iskut region, northern British Columbia, Canada. Journal of Paleolimnology 28, 419-31.

Stuiver, M., Reimer, P.J., Bard, E., Beck, J.W., Burr, G.S., Hughen, K.A., Kromer, B., McCormac, G., van der Plicht, J. and Spurk, M. 1998: Intcal98 radiocarbon age calibration, $24000-0$ cal BP. Radiocarbon 40, 1041-83.

Valsecchi, V., Tinner, W., Finsinger, W. and Ammann, B. 2006 Human impact during the Bronze Age on the vegetation at Lago Lucone (northern Italy). Vegetation History and Archaeobotany 15 , 99-113.

van Geel, B., Buurman, J. and Waterbolk, H.T. 1996: Archaeological and palaeoecological indications of an abrupt climate change in The Netherlands, and evidence for climatological teleconnections around 2650 BP. Journal of Quaternary Science 11, 451-60.
Vincens, A., Williamson, D., Thevenon, F., Taieb, M., Buchet, G., Decobert, M. and Thouveny, N. 2003: Pollen-based vegetation changes in southern Tanzania during the last 4200 years: climatic change and/or human impact. Palaeogeography, Palaeoclimatology, Palaeoecology 198, 321-34.

Wallinga, J. 2002: Optically stimulated luminescence dating of fluvial deposits: a review. Boreas 31, 303-22.

Wenzens, G. 1999: Fluctuations of outlet and valley glaciers in the Southern Andes (Argentina) during the past 13000 years. Quaternary Research 51, 238-47.

Zabenskie, S. and Gajewski, K. 2007: Post-glacial climatic change on Boothia Peninsula, Nunavut, Canada. Quaternary Research 68, 261-70.

Zolitschka, B., Behre, K.E. and Schneider, J. 2003: Human and climatic impact on the environment as derived from coluvial, fluvial and lacustrine archives - examples from the Bronze Age to the Migration period, Germany. Quaternary Science Reviews 22, 81-100. 
Copyright of Holocene is the property of Sage Publications, Ltd. and its content may not be copied or emailed to multiple sites or posted to a listserv without the copyright holder's express written permission. However, users may print, download, or email articles for individual use. 